\title{
In Situ Monitoring of Pulsed Laser Annealing of Eu-Doped Oxide Thin Films
}

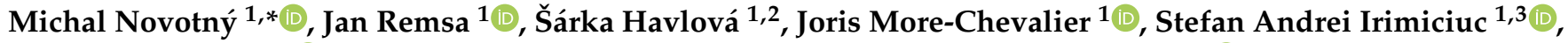 \\ Sergii Chertopalov ${ }^{1}{ }^{1}$, Petr Písařík ${ }^{1}$, Lenka Volfová ${ }^{1,4}$, Přemysl Fitl ${ }^{1}$, Tomáš Kmječ ${ }^{1}$, Martin Vrňata ${ }^{2}$ \\ and Ján Lančok ${ }^{1}$ (1)
}

1 Institute of Physics of the Czech Academy of Sciences, 18221 Prague, Czech Republic; remsa@fzu.cz (J.R.); havlova@fzu.cz (Š.H.); morechevalier@fzu.cz (J.M.-C.); stefan.irimiciuc@inflpr.ro (S.A.I.); chertopalov@fzu.cz (S.C.); pisarik@fzu.cz (P.P.); volfl@fzu.cz (L.V.); fitlp@vscht.cz (P.F.); kmjec@fzu.cz (T.K.); lancok@fzu.cz (J.L.)

2 Department of Physics and Measurements, University of Chemistry and Technology, 16628 Prague, Czech Republic; vrnatam@vscht.cz

3 National Institute for Laser, Plasma and Radiation Physics (INFLPR), 077125 Măgurele, Romania

4 Faculty of Science, Charles University, 12840 Prague, Czech Republic

* Correspondence: novotnym@fzu.cz

Citation: Novotný, M.; Remsa, J.; Havlová, Š.; More-Chevalier, J.; Irimiciuc, S.A.; Chertopalov, S.; Písařík, P.; Volfová, L.; Fitl, P.; Kmječ, T.; et al. In Situ Monitoring of Pulsed Laser Annealing of Eu-Doped Oxide Thin Films. Materials 2021, 14, 7576. https://doi.org/10.3390/ma14247576

Academic Editor: Adam Watras

Received: 4 November 2021

Accepted: 7 December 2021

Published: 9 December 2021

Publisher's Note: MDPI stays neutral with regard to jurisdictional claims in published maps and institutional affiliations.

Copyright: (C) 2021 by the authors. Licensee MDPI, Basel, Switzerland. This article is an open access article distributed under the terms and conditions of the Creative Commons Attribution (CC BY) license (https:/ / creativecommons.org/licenses/by/ $4.0 /)$.

\begin{abstract}
Eu}^{3+}$-doped oxide thin films possess a great potential for several emerging applications in optics, optoelectronics, and sensors. The applications demand maximizing $\mathrm{Eu}^{3+}$ photoluminescence response. Eu-doped $\mathrm{ZnO}, \mathrm{TiO}_{2}$, and $\mathrm{Lu}_{2} \mathrm{O}_{3}$ thin films were deposited by Pulsed Laser Deposition (PLD). Pulsed UV Laser Annealing (PLA) was utilized to modify the properties of the films. In situ monitoring of the evolution of optical properties (photoluminescence and transmittance) at PLA was realized to optimize efficiently PLA conditions. The changes in optical properties were related to structural, microstructural, and surface properties characterized by X-ray diffraction (XRD) and atomic force microscopy (AFM). The substantial increase of $\mathrm{Eu}^{3+}$ emission was observed for all annealed materials. PLA induces crystallization of $\mathrm{TiO}_{2}$ and $\mathrm{Lu}_{2} \mathrm{O}_{3}$ amorphous matrix, while in the case of already nanocrystalline $\mathrm{ZnO}$, rather surface smoothening0related grains' coalescence was observed.
\end{abstract}

Keywords: pulsed laser deposition; pulsed laser annealing; zinc oxide; lutetium oxide; titanium oxide; europium; in situ monitoring; photoluminescence

\section{Introduction}

$\mathrm{Eu}^{3+}$-doped oxide thin films possess great potential for several emerging applications in optics, optoelectronics, and sensors, i.e., waveguides, display luminophores, imaging detectors, solar cells, and scintillators [1-11]. $\mathrm{Eu}^{3+}$ was the dopant of choice in relation to the previously mentioned applications due to its strong emission in the visible part of spectra centered at around $612 \mathrm{~nm}$ [12]. As an example of well-known $\mathrm{Eu}^{3}$ dopant host matrices we can mention semiconducting $\mathrm{ZnO}, \mathrm{TiO}_{2}$, and dielectric $\mathrm{Lu}_{2} \mathrm{O}_{3}$ oxides. The Eu ${ }^{3+}$-doped thin films are fabricated by a variety of methods [1,2], e.g., ion implantation [13], plasmaenhanced chemical vapor deposition $[3,4,14]$, electrochemical deposition [5], hydrothermal deposition [15,16], chemical bath deposition [6], spraying [17,18], sputtering [4,7,8,19-21], evaporation [22,23], pulsed laser deposition (PLD) [24-27], matrix-assisted pulsed laser evaporation technique (MAPLE) [28], and sol-gel [9,10,29-33].

Post-deposition thermal treatment is usually required to activate the Eu ions and optimize the photoluminescence (PL) response $[4,8,9,13,14,16,17,19-21,26,28-30,32,33]$. However, the methods used for conventional thermal annealing require heating the samples to high temperature $\left(>700^{\circ} \mathrm{C}\right)$ for sufficiently long times in order for thermal diffusion of the defects to occur. The high-temperature processing limits the flexibility and practical applicability of these methods toward development of various optical and electro-optical 
devices. To address just the main disadvantages, only heat-resistant substrates can be used, undesirable crystallization of amorphous host might also occur, and, finally, the treatment of the entire sample may be undesirable in the device production.

The utilization of Pulsed Laser Annealing (PLA) to obtain and tune optically active $\mathrm{Eu}^{3+}$-doped films may profit from numerous advantages [34,35], i.e., (if necessary) horizontally structured local-rapid laser rating, ability to achieve ultra-high temperature in local scale, better controlled vertical thermal profile, controlled thermal profile, rapid processing, possibility of remote sample processing, and easy process automation. PLA plays, therefore, an important and challenging role in the development of high-tech electronic, optoelectronic, photonics, and sensing devices.

PLA technique offers a great flexibility in the number of control parameters available, i.e., laser wavelength, fluence $\left(F_{\mathrm{L}}\right)$, repetition rate $\left(f_{\text {rep }}\right)$, number of shots, and ambient atmospheres [36-38]. Finding the optimal PLA conditions strongly depends on sample properties, i.e., film thickness, optical properties, and microstructure. Therefore, in order to find the optimal PLA conditions for maximizing $\mathrm{Eu}^{3+}$ PL response, a number of testing samples will be necessary. In situ monitoring of PLA can be an effective way to reach the optimal conditions accurately and fast.

In this paper, we report on in situ monitoring optical properties of Eu-doped $\mathrm{ZnO}$, $\mathrm{TiO}_{2}$, and $\mathrm{Lu}_{2} \mathrm{O}_{3}$ thin films prepared by PLD within their processing by PLA using ArF excimer laser. Photoluminescence and optical transmittance measurement techniques were implemented. The effect of PLA on morphology, microstructure, and composition was evaluated.

\section{Materials and Methods}

$\mathrm{ZnO}: \mathrm{Eu}, \mathrm{Lu}_{2} \mathrm{O}_{3}: \mathrm{Eu}$, and $\mathrm{TiO}_{2}$ :Eu thin films were fabricated by PLD using Nd:YAG laser $(\lambda=266 \mathrm{~nm}, \tau=6 \mathrm{~ns})$ and $\mathrm{KrF}$ laser $(\lambda=248 \mathrm{~nm}, \tau=20 \mathrm{~ns})$. The targets were $\mathrm{Eu}_{2} \mathrm{O}_{3}: \mathrm{ZnO}$ (1\% at. $\mathrm{Eu}), \mathrm{Eu}_{2} \mathrm{O}_{3}: \mathrm{Lu}_{2} \mathrm{O}_{3}(3 \%$ at. $\mathrm{Eu})$, and $\mathrm{Eu}_{2} \mathrm{O}_{3}: \mathrm{TiO}_{2}(1 \%$ at. Eu). Depositions were performed in an oxygen ambient. The vacuum chamber was pumped down to an ultimate pressure of $5.10^{-4} \mathrm{~Pa}$. The films were grown on fused silica substrates maintained at room temperature. The distance between substrate and target was $50 \mathrm{~mm}$. The deposition conditions are listed in Table 1.

Table 1. The deposition and laser annealing conditions.

\begin{tabular}{cccccc}
\hline Material & $\begin{array}{c}\text { Fluence PLD } \\
\left(\mathbf{J} \cdot \mathbf{c m}^{-2}\right)\end{array}$ & $\begin{array}{c}\mathbf{O}_{2} \text { Pressure } \\
(\mathbf{P a})\end{array}$ & $\begin{array}{c}\text { Deposition Time } \\
(\mathbf{m i n})\end{array}$ & $\begin{array}{c}\text { Thickness } \\
(\mathbf{n m})\end{array}$ & $\begin{array}{c}\text { Fluence PLA } \\
\left(\mathbf{J} \cdot \mathbf{c m}^{-2}\right)\end{array}$ \\
\hline $\begin{array}{c}\mathrm{ZnO}: \mathrm{Eu} \\
(1 \% \text { at. } \mathrm{Eu})\end{array}$ & 5 & 15 & 8.3 & $840-1000$ & 175 \\
$\begin{array}{c}\mathrm{TiO} \mathrm{O}_{2}: \mathrm{Eu} \\
(1 \% \text { at. } \mathrm{Eu})\end{array}$ & 9 & 1 & 25 & 800 & 175 \\
$\mathrm{Lu}_{2} \mathrm{O}_{3}: \mathrm{Eu}$ & 5 & 2.5 & 20 & $110-150$ & 150 \\
$(3 \%$ at. $\mathrm{Eu})$ & 5 & & & & \\
\hline
\end{tabular}

PLA was performed using an $\operatorname{ArF}$ laser $(\lambda=193 \mathrm{~nm}, \tau=20 \mathrm{~ns})$ Compex PRO $205 \mathrm{~F}$ (Coherent, Inc., Santa Clara, CA, USA). To perform PLA the laser beam was focused using converging lens on the sample at the angle of $70^{\circ}$. The optical properties were analyzed sequentially after each PLA pulse or burst of pulses that were fired at $f_{\text {rep }}=1 \mathrm{~Hz}$. The signal for in situ PL was taken from the sample edge using an optical fiber connected to a spectrometer Horiba JY Triax iHR550 (Kyoto, Japan) equipped with LN cooled CCD Symphony. The same ArF laser was used for spectra excitation at lowered $F_{\mathrm{L}}=10 \mathrm{~mJ} \cdot \mathrm{cm}^{-2}$ with $f_{\text {rep }}=5 \mathrm{~Hz}$. Optical transmittance was in situ probed perpendicularly using light generated by a DH 2000 source (Ocean Insight, Orlando, FL, USA) and analyzed by a spectrometer. The PLA conditions are listed in Table 1 and the experimental setup is shown in Figure 1. 


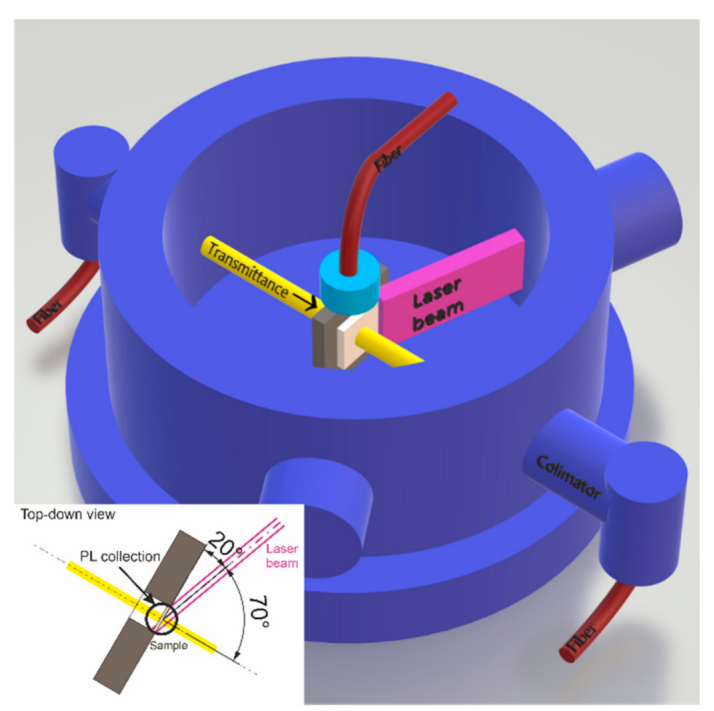

Figure 1. PLA and in situ optical properties' measurement experimental setup.

The structure of the films was characterized by X-ray diffraction (XRD) using an $X$-Ray diffractometer (EMPYREAN, Malvern Panalytical, Malvern, UK) with Cu anode $(\lambda=1.5406 \AA)$ by grazing incidence (omega $\left.=0.85^{\circ}\right)$ and Bragg-Brentano measurements at room temperature. Morphology was examined by atomic force microscopy (AFM) (Dimension Icon, Bruker, Billerica, MA, USA). Chemical composition was determined by Scanning electron microscopy-Energy-dispersive X-ray spectroscopy (SEM-EDX) (Fera 3, TESCAN, Brno, Czech Republic) and the Orbis ${ }^{\circledR}$ PC Micro-XRF spectrometer (EDAX, Ametek, Berwyn, PA, USA), Rh X-ray tube, $40 \mathrm{kV}$, polycapillary optics, a diameter of $30 \mu \mathrm{m}$ of incident beam, and a silicon-drift detector with resolution FWHM 130 eV/Mn. The thickness measurement took place on an Alphastep IQ device (KLA-Tencor Corporation, Milpitas, CA, USA) with a scan length of $5 \mathrm{~mm}$, stylus force of $5.5 \mathrm{mg}$, and scan speed of $50 \mu \mathrm{m} \cdot \mathrm{s}^{-1}$. Each line was measured two times. The stylus diamond tip had a radius of $5 \mu \mathrm{m}$ and an angle of $60^{\circ}$.

\section{Results and Discussion}

The deposited films of all investigated materials exhibited characteristic $\mathrm{Eu}^{3+} \mathrm{PL}$ ${ }^{5} \mathrm{D}_{0} \rightarrow{ }^{7} \mathrm{~F}_{\mathrm{j}}(\mathrm{j}=0,1,2,3$, and 4$)$ emission related to $\mathrm{f}-\mathrm{f}$ transition. The observation of the $\mathrm{PL}$ emission confirmed that the energy transfer processes in $\mathrm{Eu}^{3+}$ excitation must take place considering excitation wavelength $\lambda=193 \mathrm{~nm}(6.42 \mathrm{eV})$. It can be mainly related to host absorption and marginally in case of $\mathrm{Lu}_{2} \mathrm{O}_{3}: \mathrm{Eu}$ also to the $\mathrm{O}^{2-}-\mathrm{Eu}^{3+}$ charge transfer band (CTB) $[39,40]$. Following hyper-sensitive electric dipole transition ${ }^{5} \mathrm{D}_{0} \rightarrow{ }^{7} \mathrm{~F}_{2}$, its Stark splitting and ${ }^{5} \mathrm{D}_{0} \rightarrow{ }^{7} \mathrm{~F}_{2} /{ }^{5} \mathrm{D}_{0} \rightarrow{ }^{7} \mathrm{~F}_{1}$ (magnetic dipole transition) emission ratio (asymmetry ratio), we could correlate the effect of PLA on the structural properties' modification. It provided information related to the surrounding defects and disorder around the $\mathrm{Eu}^{3+}$ ions. The ${ }^{5} \mathrm{D}_{0} \rightarrow{ }^{7} \mathrm{~F}_{1}$ transition was not considerably influenced by the surrounding of $\mathrm{Eu}^{3+}$ in the particular host. The transition ${ }^{5} \mathrm{D}_{0} \rightarrow{ }^{7} \mathrm{~F}_{2}$ dominated all emission spectra from $\mathrm{Eu}^{3+}$, suggesting the local symmetry around $\mathrm{Eu}^{3+}$ was low and deviated from an inversion center. The ${ }^{5} \mathrm{D}_{0} \rightarrow{ }^{7} \mathrm{~F}_{0}$ transition was only allowed, taking into account the electric dipole selection rule, in the following 10 site symmetries: $C_{s}, C_{1}, C_{n}$, and $C_{n v}(n=2,3,4,6)$ [12].

The values of $E_{g}$ listed in Table 2 were derived using Tauc plot-plotting $(\alpha \mathrm{hv})^{1 / \mathrm{m}}$ against photon energy $(\mathrm{h} v)$, where $\mathrm{m}$ is a parameter related to the type of transition, $\mathrm{m}=1 / 2$, and 2 corresponds to direct allowed transition and indirect allowed transition, respectively. $\mathrm{TiO}_{2}$ in anatase phase is considered as an indirect semiconductor, where $\mathrm{m}=2$ [41] while $\mathrm{ZnO}$ is a direct semiconductor $(\mathrm{m}=1 / 2)$ [42] and $\mathrm{Lu}_{2} \mathrm{O}_{3}$ is considered as a direct ultrawide band gap semiconductor $(\mathrm{m}=1 / 2)$ [43]. The $\mathrm{E}_{\mathrm{g}}$ values were obtained with error of $\pm 0.02 \mathrm{eV}$. 
Table 2. Properties, modifications after PLA.

\begin{tabular}{|c|c|c|c|c|c|}
\hline \multirow[t]{2}{*}{ Material } & \multirow{2}{*}{$\begin{array}{c}\mathrm{Eu}^{3+}\left({ }^{5} \mathrm{D}_{0} \rightarrow{ }^{7} \mathrm{~F}_{2}\right) \\
\text { PL Emission } \\
\text { Enhancement }\end{array}$} & \multicolumn{2}{|c|}{$\begin{array}{l}\text { Band Gap } E_{\mathrm{g}} \\
(\mathrm{eV})\end{array}$} & \multicolumn{2}{|c|}{$\begin{array}{c}\text { Roughness } \\
S \text { a } \\
S \text { q } \\
(\mathrm{nm})\end{array}$} \\
\hline & & $\begin{array}{c}\text { As } \\
\text { Deposited }\end{array}$ & PLA & $\begin{array}{c}\text { As } \\
\text { Deposited }\end{array}$ & PLA \\
\hline $\mathrm{ZnO}: \mathrm{Eu}$ & $4.1 \times$ & 3.28 & 3.25 & $\begin{array}{l}14.6 \\
18.1\end{array}$ & $\begin{array}{l}3.5 \\
4.6\end{array}$ \\
\hline $\mathrm{TiO}_{2}: \mathrm{Eu}$ & $5 \times$ & 3.24 & 3.23 & $\begin{array}{l}0.5 \\
0.6 \\
\end{array}$ & $\begin{array}{l}1.4 \\
1.8 \\
\end{array}$ \\
\hline $\mathrm{Lu}_{2} \mathrm{O}_{3}: \mathrm{Eu}$ & $2.8 \times$ & 5.47 & 5.51 & $\begin{array}{l}2.0 \\
3.8\end{array}$ & $\begin{array}{l}1.5 \\
3.7\end{array}$ \\
\hline
\end{tabular}

As for the chemical composition of the films, Eu dopant concentrations obtained by EDX and XRF analyses corresponded to those of the targets and any substantial variation after PLA was not detected.

In the following, let us discuss the properties' modifications of each material, Eudoped $\mathrm{ZnO}, \mathrm{TiO}_{2}$, and $\mathrm{Lu}_{2} \mathrm{O}_{3}$ by PLA, in more details.

\section{1. $\mathrm{ZnO}: \mathrm{Eu}$}

The evolution of optical properties (PL emission and transmittance spectra) of $\mathrm{ZnO}: \mathrm{Eu}$ films with increasing number of PLA shots is shown in Figures 2 and 3, respectively. Characteristic $\mathrm{Eu}^{3+}$ red emission was detected at $587.3 \mathrm{~nm}$ and $593.8 \mathrm{~nm}\left({ }^{5} \mathrm{D}_{0} \rightarrow{ }^{7} \mathrm{~F}_{1}\right)$, $609.9 \mathrm{~nm}$ and $618.8 \mathrm{~nm}\left({ }^{5} \mathrm{D}_{0} \rightarrow{ }^{7} \mathrm{~F}_{2}\right), 654.8 \mathrm{~nm}\left({ }^{5} \mathrm{D}_{0} \rightarrow{ }^{7} \mathrm{~F}_{3}\right)$, and $691.5 \mathrm{~nm}, 692.8 \mathrm{~nm}$ and $704.4 \mathrm{~nm}\left({ }^{5} \mathrm{D}_{0} \rightarrow{ }^{7} \mathrm{~F}_{4}\right)$. The spectra in Figure 2 revealed that different emitting centers related to Eu may coexist in $\mathrm{ZnO}: \mathrm{Eu}$ films, which is commonplace for wide band gap materials of wurtzite structure [44]. Eu ${ }^{3+}$ ions in $\mathrm{ZnO}$ :Eu films generally occupy the substitutional sites of $\mathrm{Zn}^{2+}$ ions. This fact turns ${ }^{5} \mathrm{D}_{0} \rightarrow{ }^{7} \mathrm{~F}_{1}$ and ${ }^{5} \mathrm{D}_{0} \rightarrow{ }^{7} \mathrm{~F}_{2}$ transitions to be allowed. The observation of ${ }^{5} \mathrm{D}_{0} \rightarrow{ }^{7} \mathrm{~F}_{2}$ transition splitting suggests that $\mathrm{Eu}^{3+}$ can be at a substitutional Zn site $\left(C_{3 v}\right.$ symmetry). We could not observe clear evidence of ${ }^{5} \mathrm{D}_{0} \rightarrow{ }^{7} \mathrm{~F}_{0}$ transition whose appearance in PL spectra of $\mathrm{ZnO}: \mathrm{Eu}$ was related with $\mathrm{Eu}^{3+}$ presence in other sites (e.g., the interstitial sites or surface/grain boundary of $\mathrm{ZnO}$ nanocrystals) $[33,45,46]$. A potential drawback of our interpretation can be the relatively low intensity of the PL signal. However, if we expect only a small fraction of $\mathrm{Eu}^{3+}$ in the sample located at $\mathrm{ZnO}$ nanocrystals' surface, $\mathrm{Eu}^{3+}$ emission lines' intensities and asymmetric ratio would increase with the increasing number of PLA shots, while the asymmetric ratio saturated at $N_{\#}=400$, as it is depicted in Figure 2. The enhancement of $\mathrm{Eu}^{3+} \mathrm{PL}$ intensity at $609.9 \mathrm{~nm}$ by a factor of $4.1 \times$ was obtained. The PL signal intensity and asymmetric ratio variations might be related to microstructure modification, as displayed in Figure 4, where grains coalescing took place. It was reported that the energy relaxation process of excited $\mathrm{Eu}^{3+}$ ions should play a more important role toward PL efficiency enhancement than the energy transfer process from $\mathrm{ZnO}$ matrix to $\mathrm{Eu}^{3+}$ ions [47].

The transmittance spectra shown in Figure 3 confirm good quality of the film because transmittance of $\sim 80 \%$ was reached in the visible light spectrum (VIS) band. There was not noticeable any variation in transmittance spectra, which confirmed that defects like oxygen vacancies were not introduced during the PLA processing. Band gap value decreased after PLA from $E_{g} \sim 3.28 \mathrm{eV}$ to $3.25 \mathrm{eV}$. Recently, we observed similar $\mathrm{E}_{\mathrm{g}}$ values and trends at $\mathrm{ZnO}: \mathrm{Eu}$ film PLD deposited at a substrate temperature of $300^{\circ} \mathrm{C}$ [24].

AFM images of the film surface presented in Figure 4 revealed that PLA caused interconnecting of the grains accompanied by substantial lowering of surface roughness, as depicted in Table 2. We could attribute this effect to reaching the melting threshold of $\mathrm{ZnO}: \mathrm{Eu}$ thin film. Similar results of UV PLA on the surface morphology of $\mathrm{ZnO}$ 
thin film of comparable thickness deposited by PLD on quartz substrate were reported at higher $\mathrm{F}_{\mathrm{L}} \geq 140 \mathrm{~mJ} / \mathrm{cm}^{2}$, where coalesced nanoclusters kept the wurtzite crystalline structure [36]. The PLA-induced coalescence of nanoparticles was also reported at $\mathrm{ZnO}$ [48] and $\mathrm{ZnO}: \mathrm{Eu}$ [37] films of lower thickness $<60 \mathrm{~nm}$ on metal and $\mathrm{Si}$ substrates, respectively.

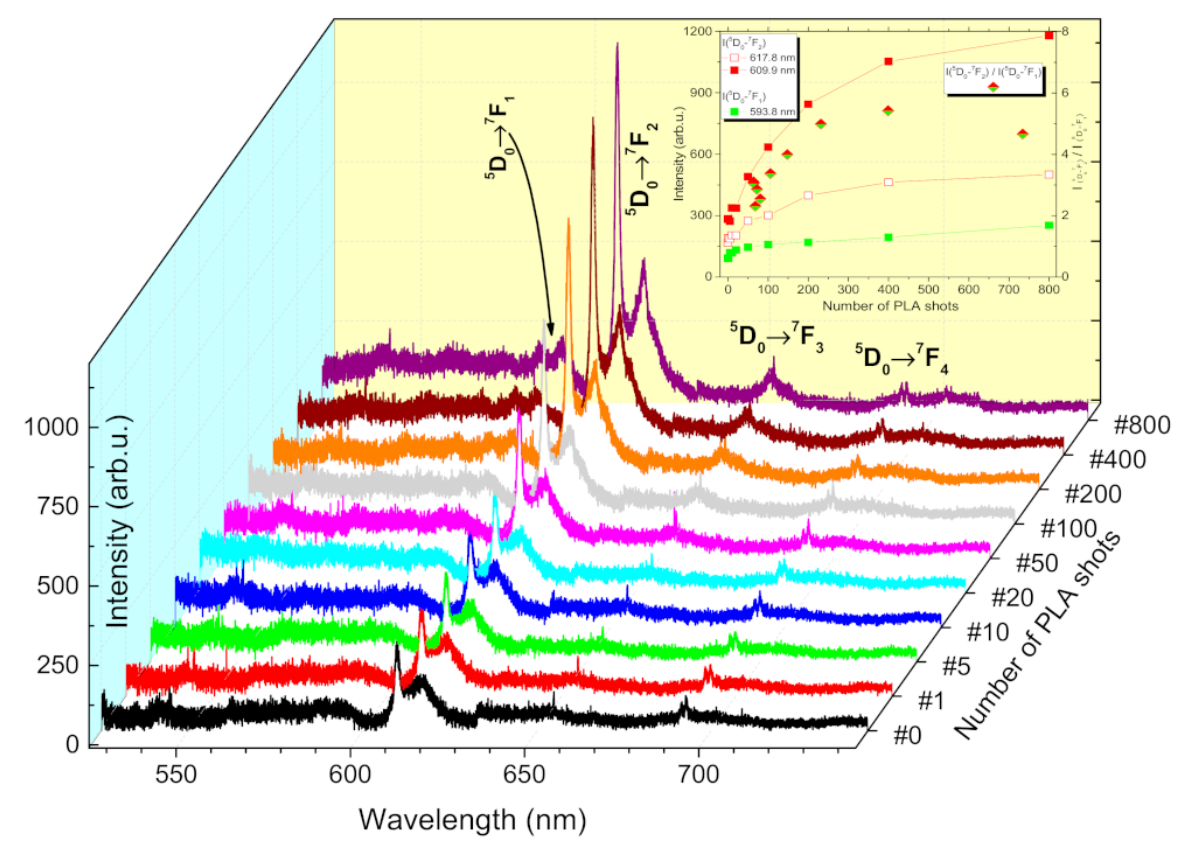

Figure 2. PL emission spectra of $\mathrm{ZnO}: \mathrm{Eu}$ thin film, dependence on the number of PLA shots.

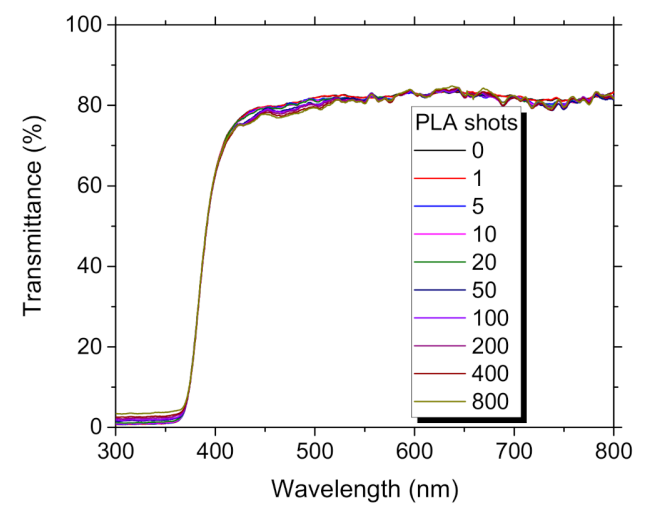

Figure 3. Transmittance spectra $\mathrm{ZnO}: \mathrm{Eu}$ thin film, dependence on the number of PLA shots.

(a)

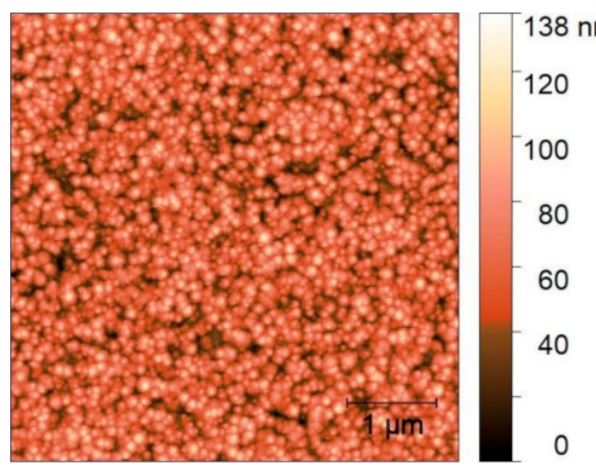

(b)

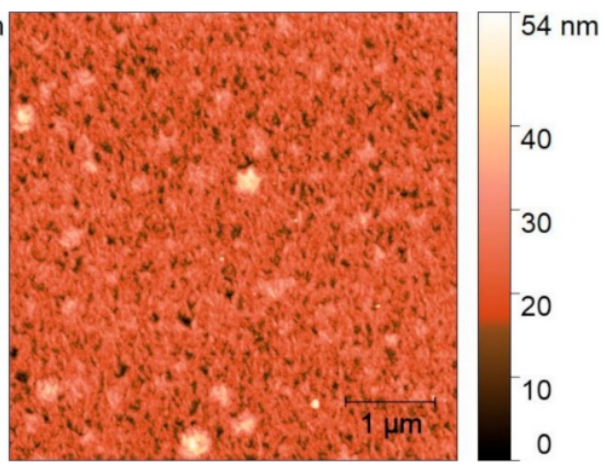

Figure 4. AFM surface images of $\mathrm{ZnO}: \mathrm{Eu}$ thin film (a) as deposited and (b) after PLA processing, 800 shots. 
XRD patterns of as-deposited and PLA-treated ZnO:Eu film, shown in Figure 5, did not reveal any substantial changes in structural properties. This fact is in good correlation with our previous results dedicated to PLA of $\mathrm{ZnO}$ :Eu film by $\mathrm{KrF}$ laser [37]. The film exhibited a hexagonal wurtzite structure of fibrous texture along the c-axes with random lateral orientations of crystallites. The FWHM of the strongest (002) peak was used to estimate the average crystallite size by using the Scherrer's formula and were $\approx 19 \mathrm{~nm}$. This correlated with the AFM measurement data. The presence of additional phases, such as $\mathrm{Eu}_{2} \mathrm{O}_{3}$, was not detected. Considering the larger ionic radius of $\mathrm{Eu}^{2+}(1.13 \AA)$ than $\mathrm{Eu}^{3+}$ $(0.95 \AA)$ in comparison with $\mathrm{Zn}^{2+}(0.74 \AA)$, substitution of $\mathrm{Eu}^{3+}$ ions at $\mathrm{Zn}^{2+}$ sites seemed to be more favorable than that of $\mathrm{Eu}^{2+}$ ions but charge compensation must take place [24].

(a)

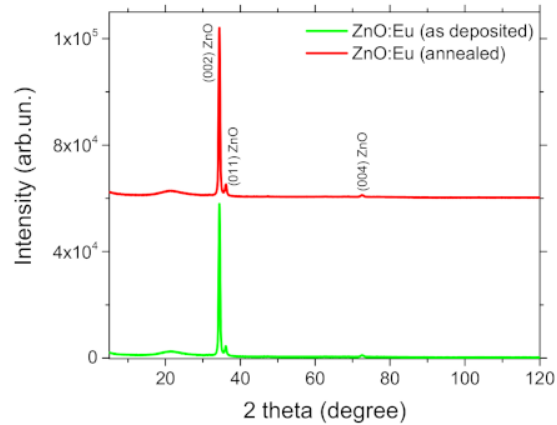

(b)

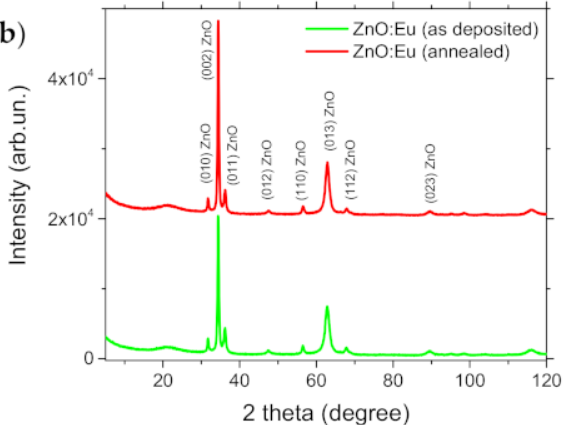

Figure 5. XRD patterns of ZnO:Eu thin film (as deposited and after PLA processing, 800 shots), (a) 2theta-omega and (b) grazing incidence scans.

\section{2. $\mathrm{TiO}_{2}: \mathrm{Eu}$}

The dependence of optical properties of $\mathrm{TiO}_{2}$ :Eu films, i.e., PL emission and transmittance spectra, on the number of PLA shots is presented in Figures 6 and 7, respectively. The transmittance spectra underline the high quality of the film because any evident absorption in VIS that can be related to defects such as oxygen vacancies and a presence of Ti suboxides did not appear [28]. We could observe a weak broadened emission line of $\mathrm{Eu}^{3+}$ for the as-grown, which is characteristic for the amorphous phase [49]. The increase of $\mathrm{Eu}^{3+}$ PL intensity accompanied by sharpening lines of split ${ }^{5} \mathrm{D}_{0} \rightarrow{ }^{7} \mathrm{~F}_{2}$ transition, as depicted in Figure 6, as well as a slight increase of transmittance (1.3\%) are corelated to surface modification and gradual crystallization of $\mathrm{TiO}_{2}$ matrix. The significant increase of $\mathrm{Eu}^{3+}$ PL intensity $(\sim 5 \times)$ was detected at $\mathrm{N}_{\#}=50$, where transmittance decreased and further remained constant. $\mathrm{TiO}_{2}$ nanocrystallites formed by PLA may act as sensitizers absorbing the excitation energy more efficiently $[31,49]$. We can recognize splitting ${ }^{5} \mathrm{D}_{0} \rightarrow{ }^{7} \mathrm{~F}_{2}$ transition to peaks located at $611.1 \mathrm{~nm}, 614 \mathrm{~nm}, 616.9 \mathrm{~nm}, 624 \mathrm{~nm}$, and $626.1 \mathrm{~nm}$. The splitting may indicate $\mathrm{Eu}^{3+}$ located in $\mathrm{D}_{2}$ and $\mathrm{S}_{4}$ symmetry sites of $\mathrm{TiO}_{2}$ [49]. The slight decrease of $\mathrm{Eu}^{3+}$ PL intensity of ${ }^{5} \mathrm{D}_{0} \rightarrow{ }^{7} \mathrm{~F}_{2}$ transitions at $616.9 \mathrm{~nm}$ and $624 \mathrm{~nm}$ after $\mathrm{N}_{\#}=200$ can be attributed to the creation of well-crystalized anatase $\mathrm{TiO}_{2}$ matrix $[28,50]$. Because the intensity of ${ }^{5} \mathrm{D}_{0} \rightarrow{ }^{7} \mathrm{~F}_{1}$ transition was weak, it made it impossible to conclude on its splitting. The ${ }^{5} \mathrm{D}_{0} \rightarrow{ }^{7} \mathrm{~F}_{0}$ transition could not be followed at all, which may exclude Eu ${ }^{3+}$ occupying $\mathrm{C}_{2 \mathrm{v}}$ symmetry sites. Concerning transmittance, we must notice that its variation within PLA processing was generally rather weak. Its relative variation was less than $2 \%$, which is slightly above the measurement error.

We did not obtain any shift in $\mathrm{E}_{\mathrm{g}}$ value after PLA, as listed in Table 2. Similar values of $\mathrm{E}_{\mathrm{g}} \sim 3.22 \mathrm{eV}$ for $\mathrm{TiO}_{2}$ material [51] and anatase-like thin $\mathrm{TiO}_{2}$ films [52] were reported. There are reports of higher $\mathrm{Eg} \sim 3.3 \mathrm{eV}$ for $\mathrm{TiO}_{2}$ : $\mathrm{Eu}$ films deposited by the spray pyrolysis technique. Our $\mathrm{E}_{\mathrm{g}}$ values suggested we did not introduce defects in the films since lowering $\mathrm{E}_{\mathrm{g}}$ from $3.03 \mathrm{eV}$ to $2.52 \mathrm{eV}$ was observed after aerodynamic levitated laser annealing of defect-rich (oxygen vacancies) $\mathrm{TiO}_{2}$ nanoparticles [53]. Lower $\mathrm{E}_{\mathrm{g}} \sim 2.7 \mathrm{eV}$ was also reported for $\mathrm{TiO}_{2}$ : $\mathrm{Eu}$ films prepared by MAPLE, where $\mathrm{E}_{\mathrm{g}}$ value shift was related to interstitial Eu doping [28]. 


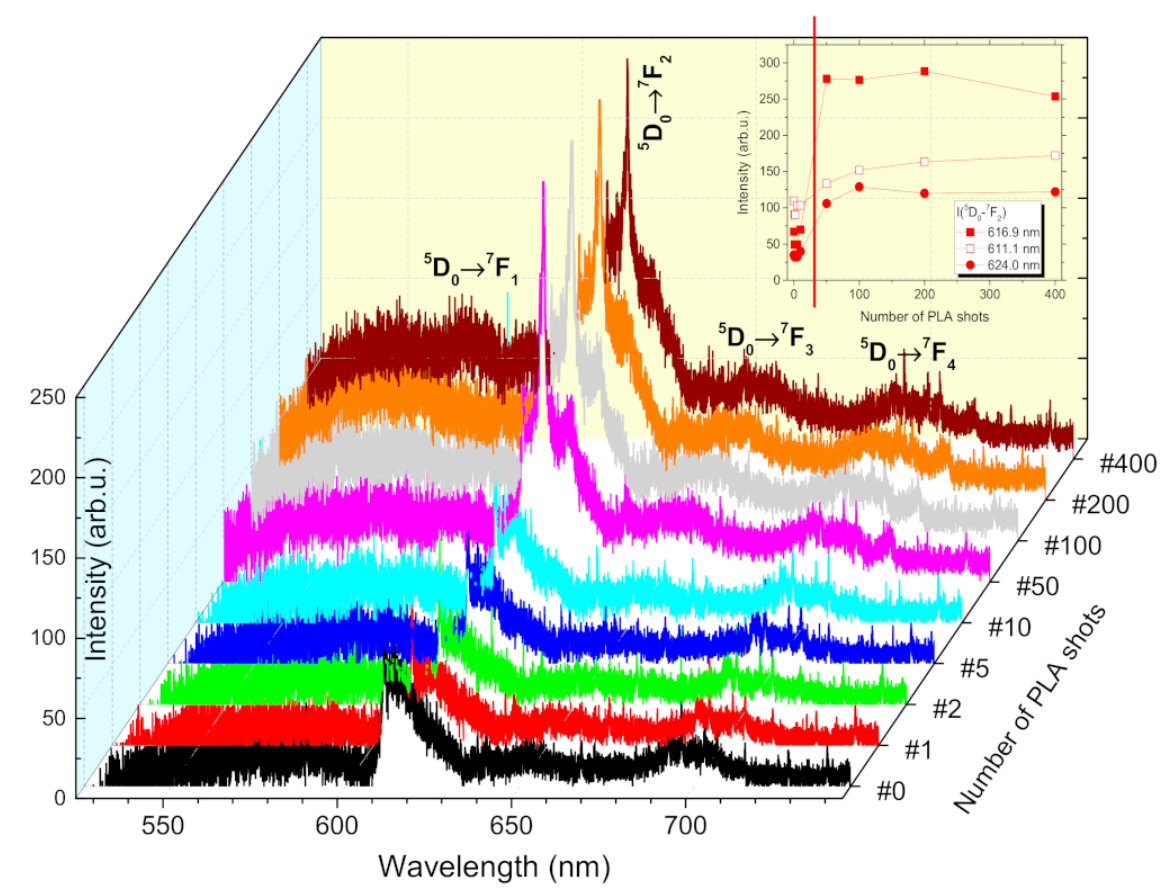

Figure 6. PL emission spectra of $\mathrm{TiO}_{2}$ :Eu thin film, dependence on the number of PLA shots.

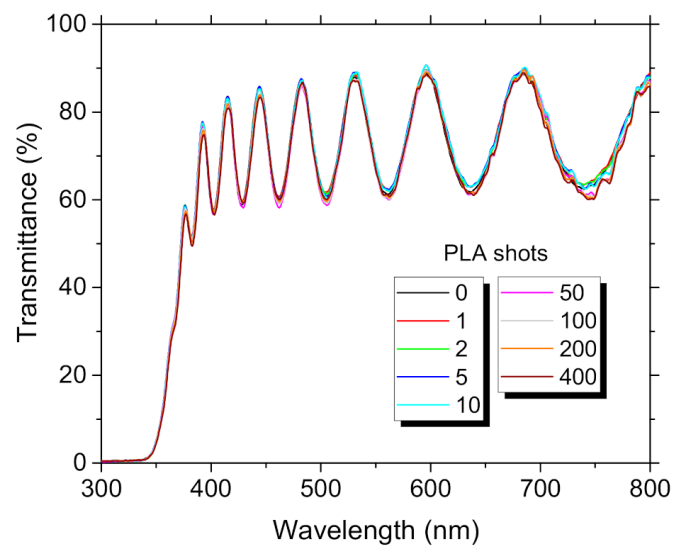

Figure 7. Transmittance spectra $\mathrm{TiO}_{2}:$ Eu thin film, dependence on the number of PLA shots.

An AFM image of the film surface, shown in Figure 8, revealed clear evidence of crystallization of the film after PLA, as observed by XRD. The growth of grains is reflected by the increasing roughness, as depicted in Table 2.

(a)
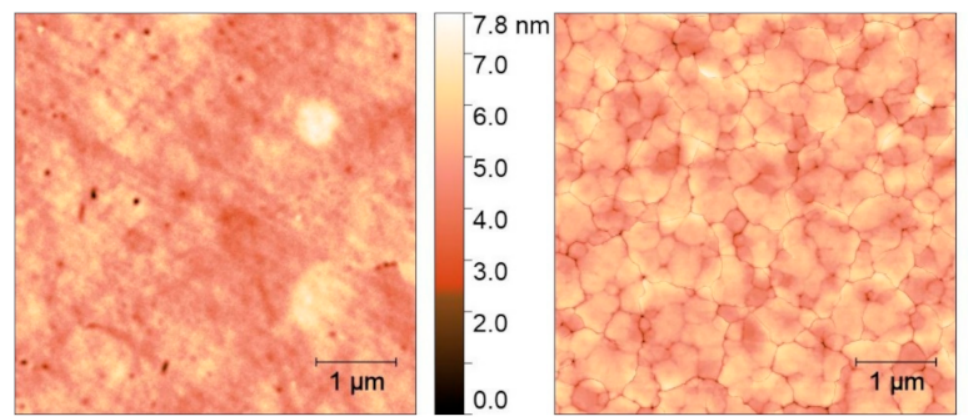

$21.6 \mathrm{~nm}$

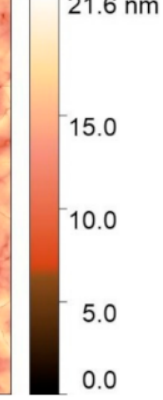

(b)

Figure 8. AFM surface images of TiO:Eu thin film (a) as deposited and (b) after PLA processing, 400 shots. 
XRD analyses, shown in Figure 9, revealed the amorphous character of as-grown film, while the PLA-treated film exhibited polycrystalline tetragonal anatase phase $\mathrm{TiO}_{2}$, as referred in the JCPDS Card NO: 96-500-0224 file. Peak positions and reflections' planes derived from XRD patterns were $25.38^{\circ}(011), 36.78^{\circ}(013), 37.68^{\circ}(004), 48.03^{\circ}(020)$, $53.68^{\circ}(015)$, and $55.08^{\circ}(121)$. Crystallites' size was derived using Sherrer's formula and was $\approx 46.1 \mathrm{~nm}$. Anatase $\mathrm{TiO}_{2}$ phase was also obtained by $\mathrm{KrF}$ PLA of nanoparticles at $\mathrm{F}_{\mathrm{L}}=34 \mathrm{~mJ} / \mathrm{cm}^{2}$, while at a higher $\mathrm{F}_{\mathrm{L}}$ a rutile phase appeared [54]. The crystallization of divalent- or trivalent europium-containing oxide compounds or europium titanate [55] was not detected by XRD. The large mismatch in the ion radii of $\mathrm{Eu}^{3+}$ and $\mathrm{Ti}^{4+}, 0.95 \mathrm{~A}$ and $0.68 \mathrm{~A}$, respectively, may cause a crystal structural distortion and also make difficult the substitution of $\mathrm{Ti}^{4+}$ by $\mathrm{Eu}^{3+}$ within the anatase lattice [31].

(a)

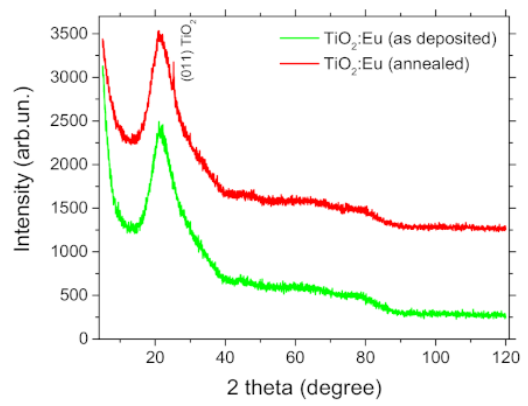

(b)

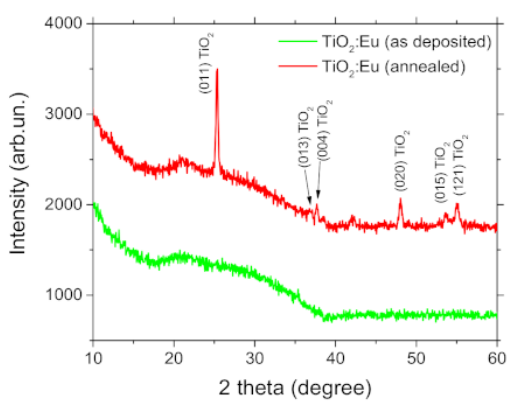

Figure 9. $\mathrm{XRD}$ patterns of $\mathrm{TiO}_{2}$ :Eu thin film (as deposited and after PLA processing, 400 shots), (a) 2theta-omega and (b) grazing incidence scans.

\section{3. $\mathrm{Lu}_{2} \mathrm{O}_{3}: \mathrm{Eu}$}

The PL emission spectra of $\mathrm{Lu}_{2} \mathrm{O}_{3}: \mathrm{Eu}$ film, shown in Figure 10, exhibited a strong luminescence signal of $\mathrm{Eu}^{3+}$ attributed to transition ${ }^{5} \mathrm{D}_{0} \rightarrow{ }^{7} \mathrm{~F}_{\mathrm{j}}(\mathrm{j}=0-4)$ as well as a lower intensity signal from transition ${ }^{5} \mathrm{D}_{1} \rightarrow{ }^{7} \mathrm{~F}_{\mathrm{j}}(\mathrm{j}=1-2)$. The excitation efficiency by ArF laser at $\lambda_{\text {exc }}=193 \mathrm{~nm}$ profited from $\mathrm{Lu}_{2} \mathrm{O}_{3}$ host lattice broad absorption band centered around $\lambda=210 \mathrm{~nm}$ [40]. Let us notice that the appearance of ${ }^{5} \mathrm{D}_{1} \rightarrow{ }^{7} \mathrm{~F}_{\mathrm{j}}(\mathrm{j}=1-2)$ transitions is much less common in $\mathrm{Eu}^{3+}$-doped materials. These transitions could be observed in compounds with low-lattice phonon energy, e.g., Lu-O that leads to multiphonon relaxation $[12,56]$. They were also reported at films grown by chemical vapor deposition (CVD) [3]. Concerning ${ }^{5} \mathrm{D}_{0} \rightarrow{ }^{7} \mathrm{~F}_{\mathrm{j}}(\mathrm{j}=0-2)$ transitions, the PL spectrum revealed similar features as the spectrum (excited at $\lambda_{\text {exc }}=254 \mathrm{~nm}$ ) of PLD-prepared $\mathrm{Lu}_{2} \mathrm{O}_{3}:$ Eu film with $5 \%$ Eu content [27]. Transitions were composed of peaks at $580.2 \mathrm{~nm}$ for ${ }^{5} \mathrm{D}_{0} \rightarrow{ }^{7} \mathrm{~F}_{0}\left(\mathrm{Eu}^{3+}\right.$ in the noncentrosymmetric $C_{2}$ site [57]); $582.2 \mathrm{~nm}, 586.7 \mathrm{~nm}, 593.1 \mathrm{~nm}$, and $600.3 \mathrm{~nm}$ for ${ }^{5} \mathrm{D}_{0} \rightarrow{ }^{7} \mathrm{~F}_{1}\left(\mathrm{Eu}^{3+}\right.$ in the $C_{2}$ and $S_{6}$ (centrosymmetric) sites [40,58]); $611.0 \mathrm{~nm}, 612.6 \mathrm{~nm}, 624 \mathrm{~nm}$, and $632 \mathrm{~nm}$ for ${ }^{5} \mathrm{D}_{0} \rightarrow{ }^{7} \mathrm{~F}_{2}\left(\mathrm{Eu}^{3+}\right.$ exclusively in the $\mathrm{C}_{2}$ site $\left.[40,58]\right) ; 650.2 \mathrm{~nm}$ and $664 \mathrm{~nm}$ for ${ }^{5} \mathrm{D}_{0} \rightarrow{ }^{7} \mathrm{~F}_{3}$; $708 \mathrm{~nm}, 710.1 \mathrm{~nm}$, and $713.5 \mathrm{~nm}$ for ${ }^{5} \mathrm{D}_{0} \rightarrow{ }^{7} \mathrm{~F}_{4} ; 533.4 \mathrm{~nm}$ for ${ }^{5} \mathrm{D}_{1} \rightarrow{ }^{7} \mathrm{~F}_{1} ;$ and $553.6 \mathrm{~nm}$ for ${ }^{5} \mathrm{D}_{1} \rightarrow{ }^{7} \mathrm{~F}_{2}$. The most intense peak observed at $611 \mathrm{~nm}$ is characteristic of the cubic phase of rare earth sesquioxides $[25,32,40]$.

We noticed the most substantial change in the film optical properties, shown in Figures 10 and 11, after the first PLA shot. The most substantial increase of Eu ${ }^{3+}$ intensity emission and optical transmittance was obtained. The $\mathrm{E}_{\mathrm{g}}$ value shifted from $5.47 \mathrm{eV}$ to $5.51 \mathrm{eV}$, where the latter values corresponded to those reported for evaporated $\mathrm{Lu}_{2} \mathrm{O}_{3}$ films $[43,59]$. This may be attributed to both surface and structure modifications (as observed by AFM and XRD in Figures 12 and 13, respectively). The asymmetric ratio increased from 7.9 to 9.5 reached at $N_{\#}=2$, which is reflecting the site symmetry decreasing related with film structure modification. The asymmetric ratio value was then decreasing to 9 and not changing for $\mathrm{N}_{\#}=4-7$. PLA led to the maximum enhancement of 2.8 times for $\mathrm{Eu}^{3+}$ intensity emission at $611.0 \mathrm{~nm}$. The energy transfer from $\mathrm{Eu}^{3+}$ residing in $\mathrm{S}_{6}$ to $\mathrm{Eu}^{3+}$ in $\mathrm{C}_{2}$ may take place because the levels of $\mathrm{Eu}^{3+}$ in the site $\mathrm{S}_{6}$ lie above those for site $\mathrm{C}_{2}$. It was reported, based on following the ${ }^{5} \mathrm{D}_{0} \rightarrow{ }^{7} \mathrm{~F}_{1} /{ }^{5} \mathrm{D}_{0} \rightarrow{ }^{7} \mathrm{~F}_{0}$ ratio, that the rate of the 
energy transfer may change with the crystallites' sizes (it is lower for larger crystallites) or because the location of $\mathrm{Eu}^{3+}$ in $\mathrm{C}_{2}$ site is more common for small crystallites [57,60]. We did not observe any considerable variation of this ratio within the PLA process, although the crystallites' size varied, as confirmed by XRD.

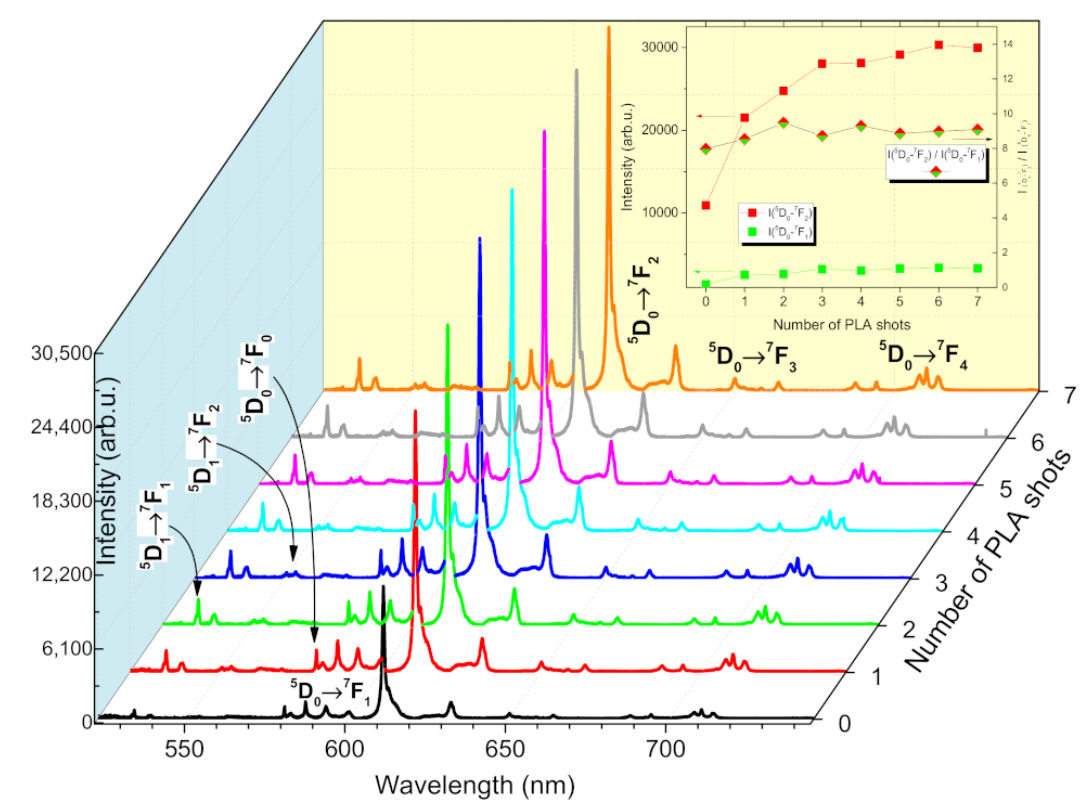

Figure 10. Emission spectra of $\mathrm{Lu}_{2} \mathrm{O}_{3}$ :Eu thin film, dependence on the number of PLA shots.

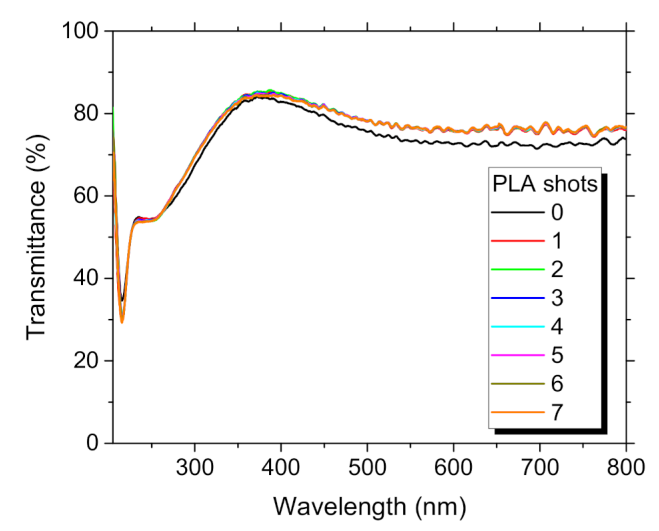

Figure 11. Transmittance spectra $\mathrm{Lu}_{2} \mathrm{O}_{3}$ :Eu thin film, dependence on the number of PLA shots.

(a)

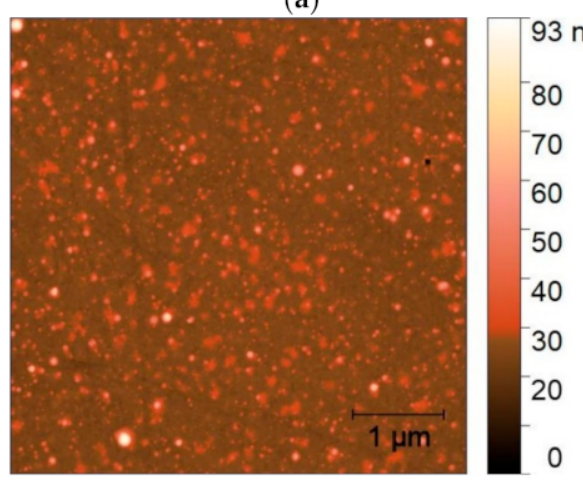

(b)

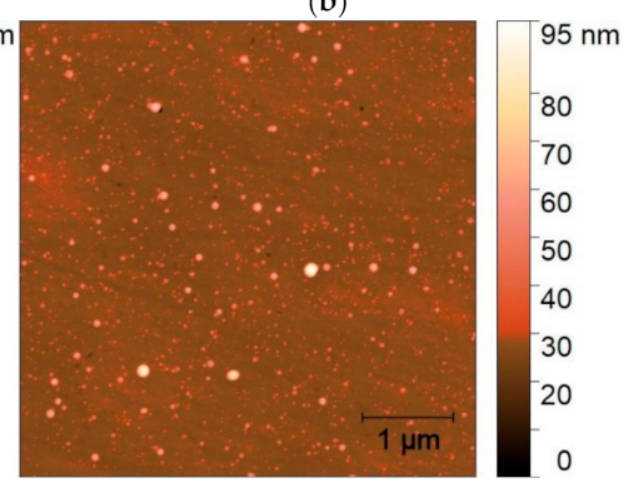

Figure 12. AFM surface images of $\mathrm{Lu}_{2} \mathrm{O}_{3}$ :Eu thin film (a) as deposited and (b) after PLA processing, seven shots. 
(a)

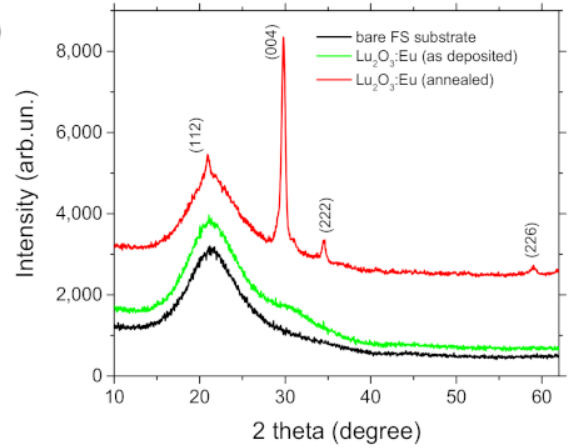

(b)

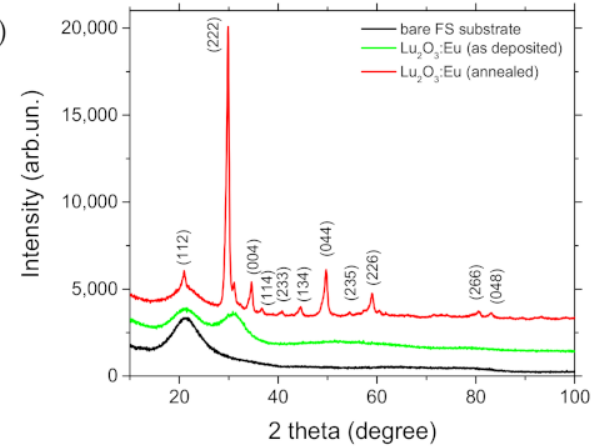

Figure 13. XRD patterns of $\mathrm{Lu}_{2} \mathrm{O}_{3}$ :Eu thin film (as deposited and after PLA processing, seven shots), (a) 2theta-omega and (b) grazing incidence scans.

AFM analyses, shown in Figure 12, revealed similar morphology for as-deposited and PLA-treated film with typical $S_{\mathrm{q}}=3.7 \mathrm{~nm}$. Slight surface smoothing was observed after PLA and $S_{a}$ decreased from $2.04 \mathrm{~nm}$ to $1.48 \mathrm{~nm}$.

A substantial improvement of the crystalline structure after PLA treatment was evidenced by XRD diffraction patterns, depicted in Figure 13. While as-deposited film was rather amorphous, the film revealed a polycrystalline structure after seven PLA shots. The estimated crystallites' size was $10.9 \mathrm{~nm}$. The similar XRD pattern was observed for $\mathrm{Lu}_{2} \mathrm{O}_{3}: \mathrm{Eu}$ films deposited by PLD at a substrate temperature higher than $400{ }^{\circ} \mathrm{C}$ [25] and by magnetron sputtering with thermal postdeposition treatment at $900{ }^{\circ} \mathrm{C}$ for $2 \mathrm{~h}$ [20]. The reflections in the XRD pattern can be assigned to a body-centered cubic (I 213 ) structure of $\mathrm{Lu}_{2} \mathrm{O}_{3}$, according to JCPDS Card NO: 96-101-0596 file. The $\mathrm{Eu}_{2} \mathrm{O}_{3}$ phase was not detected in the patterns, confirming the Eu dopant was substituting $\mathrm{Lu}$ in $\mathrm{Lu}_{2} \mathrm{O}_{3}$ host, which was supported by the closed values of the ionic radii of $0.95 \AA$ and $0.85 \AA$ for $\mathrm{Eu}^{3+}$ and $\mathrm{Lu}^{3+}$, respectively [25]. The broad hump around $2 \theta=21^{\circ}$ is characteristic for amorphous fused silica substrate.

\section{Conclusions}

The in situ monitoring system of optical properties (photoluminescence and transmission) at pulsed laser annealing processing of Eu-doped oxide thin films was demonstrated. Eu-doped $\mathrm{ZnO}, \mathrm{TiO}_{2}$, and $\mathrm{Lu}_{2} \mathrm{O}_{3}$ films were fabricated by PLD at room temperature. The system allowed us to find quickly the optimal PLA conditions (ArF laser at $\lambda=193 \mathrm{~nm}$, fluence, and number of PLA shots) for maximizing $\mathrm{Eu}^{3+}$ photoluminescence. The $\mathrm{Eu}^{3+}$ emission enhancement of $4.1 \times, 5 \times$ and $2.8 \times$, after 800,400 , and 7 PLA shots, for $\mathrm{ZnO}, \mathrm{TiO}_{2}$, and $\mathrm{Lu}_{2} \mathrm{O}_{3}$ matrix was obtained, respectively. Transmission was markedly modified at $\mathrm{Lu}_{2} \mathrm{O}_{3}: \mathrm{Eu}$ film, where also $E_{\mathrm{g}}$ increased to $5.51 \mathrm{eV}$. On the other hand, $\mathrm{ZnO}: \mathrm{Eu}$ and $\mathrm{TiO}_{2}: \mathrm{Eu}$ films exhibited lowering $E_{\mathrm{g}}$ to $3.25 \mathrm{eV}$ and $3.23 \mathrm{eV}$, respectively. $\mathrm{TiO}_{2}: \mathrm{Eu}$ and $\mathrm{Lu}_{2} \mathrm{O}_{3}: \mathrm{Eu}$ as-deposited films exhibited an amorphous character that was modified by PLA to anatase and cubic nanocrystalline phase, respectively. In the case of $\mathrm{ZnO}: \mathrm{Eu}$, the application of PLA induced rather surface smoothening-related grains' coalescence.

Author Contributions: Writing - original draft preparation and project administration, M.N.; investigation, M.N., J.R., J.M.-C., L.V., S.A.I. and T.K.; visualization, J.R.; methodology, J.R. and S.A.I.; conceptualization, P.P.; formal analysis and data curation, Š.H., S.C. and M.V.; software and validation, P.F.; supervision, J.L. All authors have read and agreed to the published version of the manuscript.

Funding: This research and the APC was funded by Czech Science Foundation, grant number 18-17834S.

Institutional Review Board Statement: Not applicable.

Informed Consent Statement: Not applicable.

Data Availability Statement: The data that support the findings of this study are available from the corresponding author upon reasonable request. 
Acknowledgments: Many thanks to Ladislav Fekete for performing AFM measurements.

Conflicts of Interest: The authors declare no conflict of interest. The funders had no role in the design of the study; in the collection, analyses, or interpretation of data; in the writing of the manuscript; or in the decision to publish the results.

\section{References}

1. Daksh, D.; Agrawal, Y.K. Rare Earth-Doped Zinc Oxide Nanostructures: A Review. Rev. Nanosci. Nanotechnol. 2016, 5, 1-27. [CrossRef]

2. Gupta, S.K.; Sudarshan, K.; Kadam, R. Optical nanomaterials with focus on rare earth doped oxide: A Review. Mater. Today Commun. 2021, 27, 102277. [CrossRef]

3. Topping, S.G.; Sarin, V.K. CVD Lu2O3:Eu coatings for advanced scintillators. Int. J. Refract. Met. Hard Mater. 2009, $27,498-501$. [CrossRef] [PubMed]

4. Nagarkar, V.V.; Topping, S.G.; Miller, S.R.; Singh, B.; Brecher, C.; Sarin, V.K. Characterization of vapor-deposited $\mathrm{Lu}_{2} \mathrm{O}_{3}$ : Eu $\mathrm{Eu}^{3+}$ scintillator for $\mathrm{x}$-ray imaging applications. In Penetrating Radiation Systems and Applications X; International Society for Optics and Photonics: Bellingham, WA, USA, 2009; Volume 7450, p. 745003. [CrossRef]

5. Li, G.-R.; Dawa, C.-R.; Lu, X.-H.; Yu, X.-L.; Tong, Y.-X. Use of Additives in the Electrodeposition of Nanostructured Eu ${ }^{3+} / \mathrm{ZnO}^{2}$ Films for Photoluminescent Devices. Langmuir 2009, 25, 2378-2384. [CrossRef] [PubMed]

6. Chen, P.; Wang, Z.; Wang, S.; Lyu, M.; Hao, M.; Ghasemi, M.; Xiao, M.; Yun, J.-H.; Bai, Y.; Wang, L. Luminescent europium-doped titania for efficiency and UV-stability enhancement of planar perovskite solar cells. Nano Energy 2020, 69, 104392. [CrossRef]

7. Ezirmik, K.V. Concentration quenching of photoluminescence in optically transparent $\mathrm{Lu}_{2} \mathrm{O}_{3}:$ Eu thin films deposited to be used as scintillators. Mater. Res. Express 2021, 8, 016407. [CrossRef]

8. Zhu, C.; Lv, C.; Wang, C.; Sha, Y.; Li, D.; Ma, X.; Yang, D. Color-tunable electroluminescence from Eu-doped TiO(2)/p(+)-Si heterostructured devices: Engineering of energy transfer. Opt. Express 2015, 23, 2819-2826. [CrossRef] [PubMed]

9. Murillo, A.G.; Romo, F.D.J.C.; Le Luyer, C.; Ramírez, A.D.J.M.; Hernández, M.G.; Palmerin, J.M. Sol-gel elaboration and structural investigations of Lu2O3:Eu3+ planar waveguides. J. Sol-Gel Sci. Technol. 2009, 50, 359-367. [CrossRef]

10. Thoř, T.; Rubešová, K.; Jakeš, V.; Cajzl, J.; Nádherný, L.; Mikolášová, D.; Beitlerová, A.; Nikl, M. Europium-doped Lu2O3 phosphors prepared by a sol-gel method. IOP Conf. Series: Mater. Sci. Eng. 2019, 465, 012009. [CrossRef]

11. Zhang, J.; Qin, Q.; Yu, M.; Zhou, M.; Wang, Y. The photoluminescence, afterglow and up conversion photostimulated luminescence of Eu3+ doped Mg2SnO4 phosphors. J. Lumin. 2012, 132, 23-26. [CrossRef]

12. Binnemans, K. Interpretation of europium(III) spectra. Co-ord. Chem. Rev. 2015, 295, 1-45. [CrossRef]

13. Miranda, S.; Peres, M.; Monteiro, T.; Alves, E.; Sun, H.; Geruschke, T.; Vianden, R.; Lorenz, K. Rapid thermal annealing of rare earth implanted ZnO epitaxial layers. Opt. Mater. 2011, 33, 1139-1142. [CrossRef]

14. Najafi, M.; Haratizadeh, H. The effect of growth conditions and morphology on photoluminescence properties of Eu-doped ZnO nanostructures. Solid State Sci. 2015, 41, 48-51. [CrossRef]

15. Kaszewski, J.; Kiełbik, P.; Wolska, E.; Witkowski, B.; Wachnicki, Ł; Gajewski, Z.; Godlewski, M.M. Tuning the luminescence of $\mathrm{ZnO}:$ Eu nanoparticles for applications in biology and medicine. Opt. Mater. 2018, 80, 77-86. [CrossRef]

16. Wang, M.; Huang, C.; Huang, Z.; Guo, W.; Huang, J.; He, H.; Wang, H.; Cao, Y.; Liu, Q.; Liang, J. Synthesis and photoluminescence of Eu-doped $\mathrm{ZnO}$ microrods prepared by hydrothermal method. Opt. Mater. 2009, 31, 1502-1505. [CrossRef]

17. Swapna, R.; Srinivasa Reddy, T.; Venkateswarlu, K.; Kumar, M.S. Effect of Post-Annealing on the Properties of Eu Doped ZnO Nano Thin Films. Procedia Mater. Sci. 2015, 10, 723-729. [CrossRef]

18. Al-Shomar, S.M. Synthesis and characterization of $\mathrm{Eu}^{3+}$ doped $\mathrm{TiO}_{2}$ thin films deposited by spray pyrolysis technique for photocatalytic application. Mater. Res. Express 2021, 8, 026402. [CrossRef]

19. Akazawa, H.; Shinojima, H. Switching photoluminescence channels between dopant $\mathrm{Eu}^{2+}$ and $\mathrm{Eu}^{3+}$ ions in $\mathrm{ZnO}$ thin films by varying the post-annealing conditions. J. Appl. Phys. 2016, 120, 123101. [CrossRef]

20. Topping, S.G.; Park, C.H.; Rangan, S.K.; Sarin, V.K. Lutetium Oxide Coatings by PVD. MRS Online Proc. Library (OPL) 2007, 1038, 115-120. [CrossRef]

21. Roy, S.; Topping, S.; Sarin, V. Growth and Characterization of $\mathrm{Lu}_{2} \mathrm{O}_{3}$ :Eu ${ }^{3+}$ Thin Films on Single-Crystal Yttria-Doped Zirconia. JOM 2013, 65, 557-561. [CrossRef]

22. Marton, Z.; Miller, S.R.; Brecher, C.; Kenesei, P.; Moore, M.D.; Woods, R.; Almer, J.D.; Miceli, A.; Nagarkar, V.V. Efficient high-resolution hard X-ray imaging with transparent $\mathrm{Lu}_{2} \mathrm{O}_{3}:$ Eu scintillator thin films. In Medical Applications of Radiation Detectors $V$; International Society for Optics and Photonics: Bellingham, WA, USA, 2015; Volume 9594, p. 95940E. [CrossRef]

23. Márton, Z.; Bhandari, H.B.; Brecher, C.; Miller, S.R.; Singh, B.; Nagarkar, V.V. High efficiency microcolumnar Lu2O3:Eu scintillator thin film for hard X-ray microtomography. J. Physics: Conf. Ser. 2013, 425, 062016. [CrossRef]

24. Novotny, M.; Vondráček, M.; Marešová, E.; Fitl, P.; Bulí̌r, J.; Pokorný, P.; Havlová, Š.; Abdellaoui, N.; Pereira, A.; Hubík, P.; et al. Optical and structural properties of ZnO:Eu thin films grown by pulsed laser deposition. Appl. Surf. Sci. 2019, 476, 271-275. [CrossRef]

25. Martinet, C.; Pillonnet, A.; Lancok, J.; Garapon, C. Optical, structural and fluorescence properties of nanocrystalline cubic or monoclinic $\mathrm{Eu}: \mathrm{Lu}_{2} \mathrm{O}_{3}$ films prepared by pulsed laser deposition. J. Lumin. 2007, 126, 807-816. [CrossRef] 
26. Le Boulbar, E.; Millon, E.; Boulmer-Leborgne, C.; Cachoncinlle, C.; Hakim, B.; Ntsoenzok, E. Optical properties of rare earth-doped $\mathrm{TiO}_{2}$ anatase and rutile thin films grown by pulsed-laser deposition. Thin Solid Films 2014, 553, 13-16. [CrossRef]

27. Irimiciuc, S.; More-Chevalier, J.; Chertpalov, S.; Fekete, L.; Novotný, M.; Havlová, Š.; Poupon, M.; Zikmund, T.; Kůsová, K.; Lančok, J. In-situ plasma monitoring by optical emission spectroscopy during pulsed laser deposition of doped $\mathrm{Lu}_{2} \mathrm{O}_{3}$. Appl. Phys. A 2021, 127, 1-9. [CrossRef]

28. Camps, I.; Borlaf, M.; Colomer, M.T.; Moreno, R.; Duta, L.; Nita, C.; del Pino, A.P.; Logofatu, C.; Serna, R.; György, E. Structureproperty relationships for Eu doped $\mathrm{TiO}_{2}$ thin films grown by a laser assisted technique from colloidal sols. RSC Adv. 2017, 7, 37643-37653. [CrossRef]

29. Garcia-Murillo, A.; Le Luyer, C.; Dujardin, C.; Martin, T.; Garapon, C.; Pédrini, C.; Mugnier, J. Elaboration and scintillation properties of $\mathrm{Eu}^{3+}$-doped $\mathrm{Gd}_{2} \mathrm{O}_{3}$ and $\mathrm{Lu}_{2} \mathrm{O}_{3}$ sol-gel films. Nucl. Instrum. Methods Phys. Res. Sect. A Accel. Spectromet. Detect. Assoc. Equip. 2002, 486, 181-185. [CrossRef]

30. Fhoula, M.; Kallel, T.; Messaoud, M.; Dammak, M.; Cavalli, E. Morphological, spectroscopic and photocatalytic properties of Eu3+:TiO2 synthesized by solid-state and hydrothermal-assisted sol-gel processes. Ceram. Int. 2019, 45, 3675-3679. [CrossRef]

31. Frindell, K.L.; Bartl, M.H.; Popitsch, A.; Stucky, G.D. Sensitized Luminescence of Trivalent Europium by Three-Dimensionally Arranged Anatase Nanocrystals in Mesostructured Titania Thin Films. Angew. Chem. Int. Ed. 2002, 41, 959-962. [CrossRef]

32. Ramírez, A.D.J.M.; Hernández, M.G.; Murillo, A.G.; Romo, F.D.J.C.; Palmerin, J.M.; Velazquez, D.Y.M.; Jota, M.L.C. Structural and Luminescence Properties of $\mathrm{Lu}_{2} \mathrm{O}_{3}: \mathrm{Eu}^{3+}$ F127 Tri-Block Copolymer Modified Thin Films Prepared by Sol-Gel Method. Materials 2013, 6, 713-725. [CrossRef]

33. Chen, P.; X. Ma, X.; Yang, D. ZnO:Eu thin-films: Sol-gel derivation and strong photoluminescence from 5D0 $\rightarrow$ 7F0 transition of $\mathrm{Eu}^{3+}$ ions. J. Alloy. Compd. 2007, 431, 317-320. [CrossRef]

34. Can, N.; Townsend, P.D.; Hole, D.E.; Snelling, H.; Ballesteros, J.M.; Afonso, C.N. Enhancement of luminescence by pulse laser annealing of ion-implanted europium in sapphire and silica. J. Appl. Phys. 1995, 78, 6737-6744. [CrossRef]

35. Can, N.; Townsend, P.D.; Hole, D.E.; Afonso, C.N. High intensity luminescence from pulsed laser annealed europium implanted sapphire. Appl. Phys. Lett. 1994, 65, 1871-1873. [CrossRef]

36. Ozerov, I.; Arab, M.; Safarov, V.; Marine, W.; Giorgio, S.; Sentis, M.; Nanai, L. Enhancement of exciton emission from ZnO nanocrystalline films by pulsed laser annealing. Appl. Surf. Sci. 2004, 226, 242-248. [CrossRef]

37. Havlová, Š.; Novotný, M.; Fitl, P.; More-Chevalier, J.; Remsa, J.; Kiisk, V.; Kodu, M.; Jaaniso, R.; Hruška, P.; Lukáč, F.; et al. Effect of pulsed laser annealing on optical and structural properties of ZnO:Eu thin film. J. Mater. Sci. 2021, 56, 11414-11425. [CrossRef]

38. Chen, Z.; Jiang, S.; Xin, B.; Guo, R.; Miao, D. Microstructures and luminescent properties of CO2 laser annealed Y2O3:Eu3+ thin films grown on quartz fabric by electron beam evaporation. Text. Res. J. 2018, 88, 1824-1833. [CrossRef]

39. Jota, M.C.; Murillo, A.G.; Romo, F.C.; Hernández, M.G.; Ramírez, A.D.J.M.; Velumani, S.; Cruz, E.D.L.R.; Kassiba, A. Lu2O3:Eu3+ glass ceramic films: Synthesis, structural and spectroscopic studies. Mater. Res. Bull. 2014, 51, 418-425. [CrossRef]

40. Xu, M.; Zhang, W.; Dong, N.; Jiang, Y.; Tao, Y.; Yin, M. Preparation and characterization of optical spectroscopy of Lu2O3:Eu nanocrystals. J. Solid State Chem. 2005, 178, 477-482. [CrossRef]

41. Jurek, K.; Szczesny, R.; Trzcinski, M.; Ciesielski, A.; Borysiuk, J.; Skowronski, L. The Influence of Annealing on the Optical Properties and Microstructure Recrystallization of the $\mathrm{TiO}_{2}$ Layers Produced by Means of the E-BEAM Technique. Materials 2021, 14, 5863. [CrossRef] [PubMed]

42. Özgür, Ü.; Alivov, Y.I.; Liu, C.; Teke, A.; Reshchikov, M.A.; Doğan, S.; Avrutin, V.; Cho, S.J.; Morkoç, H. A comprehensive review of ZnO materials and devices. J. Appl. Phys. 2005, 98, 041301. [CrossRef]

43. Zhang, D.; Lin, W.; Lin, Z.; Jia, L.; Zheng, W.; Huang, F. Lu2O3: A promising ultrawide bandgap semiconductor for deep UV photodetector. Appl. Phys. Lett. 2021, 118, 211906. [CrossRef]

44. Peres, M.; Cruz, A.; Pereira, S.; Correia, M.R.; Soares, M.; Neves, A.; Carmo, M.; Monteiro, T.; Martins, M.; Trindade, T.; et al. Optical studies of $\mathrm{ZnO}$ nanocrystals doped with $\mathrm{Eu}^{3+}$ ions. Appl. Phys. A 2007, 88, 129-133. [CrossRef]

45. Zhang, Y.; Liu, Y.; Wu, L.; Xie, E.; Chen, J. Photoluminescence and $\mathrm{ZnO} \rightarrow \mathrm{Eu}^{3+}$ energy transfer in Eu ${ }^{3+}$-doped $\mathrm{ZnO}$ nanospheres. J. Phys. D Appl. Phys. 2009, 42, 085106. [CrossRef]

46. Ningthoujam, R.; Gajbhiye, N.S.; Ahmed, A.; Umre, S.S.; Sharma, S.J. Re-Dispersible Li ${ }^{+}$and Eu ${ }^{3+}$ Co-Doped Nanocrystalline ZnO: Luminescence and EPR Studies. J. Nanosci. Nanotechnol. 2008, 8, 3059-3062. [CrossRef]

47. Ishizumi, A.; Kanemitsu, Y. Structural and luminescence properties of Eu-doped ZnO nanorods fabricated by a microemulsion method. Appl. Phys. Lett. 2005, 86, 253106. [CrossRef]

48. Nedyalkov, N.; Koleva, M.; Nikov, R.; Atanasov, P.; Nakajima, Y.; Takami, A.; Shibata, A.; Terakawa, M. Laser nanostructuring of ZnO thin films. Appl. Surf. Sci. 2016, 374, 172-176. [CrossRef]

49. Chen, X.; Luo, W. Optical Spectroscopy of Rare Earth Ion-Doped $\mathrm{TiO}_{2}$ Nanophosphors. J. Nanosci. Nanotechnol. 2010, 10, 1482-1494. [CrossRef] [PubMed]

50. Yin, J.; Xiang, L.; Zhao, X. Monodisperse spherical mesoporous Eu-doped $\mathrm{TiO}_{2}$ phosphor particles and the luminescence properties. Appl. Phys. Lett. 2007, 90, 113112. [CrossRef]

51. Makuła, P.; Pacia, M.; Macyk, W. How To Correctly Determine the Band Gap Energy of Modified Semiconductor Photocatalysts Based on UV-Vis Spectra. J. Phys. Chem. Lett. 2018, 9, 6814-6817. [CrossRef] [PubMed] 
52. Skowronski, L.; Zdunek, K.; Nowakowska-Langier, K.; Chodun, R.; Trzcinski, M.; Kobierski, M.; Kustra, M.; Wachowiak, A.; Wachowiak, W.; Hiller, T.; et al. Characterization of microstructural, mechanical and optical properties of TiO $\mathrm{T}_{2}$ layers deposited by GIMS and PMS methods. Surf. Coat. Technol. 2015, 282, 16-23. [CrossRef]

53. Wei, H.; Ma, X.; Gu, L.; Li, J.; Si, W.; Ou, G.; Yu, W.; Zhao, C.; Li, J.; Song, M.; et al. Aerodynamic levitated laser annealing method to defective titanium dioxide with enhanced photocatalytic performance. Nano Res. 2016, 9, 3839-3847. [CrossRef]

54. Pan, H.; Ko, S.H.; Misra, N.; Grigoropoulos, C.P. Laser annealed composite titanium dioxide electrodes for dye-sensitized solar cells on glass and plastics. Appl. Phys. Lett. 2009, 94, 071117. [CrossRef]

55. Serga, V.; Burve, R.; Krumina, A.; Pankratova, V.; Popov, A.I.; Pankratov, V. Study of phase composition, photocatalytic activity, and photoluminescence of $\mathrm{TiO}_{2}$ with Eu additive produced by the extraction-pyrolytic method. J. Mater. Res. Technol. 2021, 13, 2350-2360. [CrossRef]

56. Jia, G.; Zheng, Y.; Liu, K.; Song, Y.; You, H.; Zhang, H. Facile Surfactant- and Template-Free Synthesis and Luminescent Properties of One-Dimensional $\mathrm{Lu}_{2} \mathrm{O}_{3}: \mathrm{Eu}^{3+}$ Phosphors. J. Phys. Chem. C 2009, 113, 153-158. [CrossRef]

57. Zych, E.; Trojan-Piegza, J.; Kęiński, L. Homogeneously precipitated Lu2O3:Eu nanocrystalline phosphor for X-ray detection. Sens. Actuat. B Chem. 2005, 109, 112-118. [CrossRef]

58. Pedroso, C.C.S.; de Carvalho, J.M.; Rodrigues, L.C.V.; Hölsä, J.; Brito, H. Rapid and Energy-Saving Microwave-Assisted SolidState Synthesis of $\mathrm{Pr}^{3+}-, \mathrm{Eu}^{3+}-$, or $\mathrm{Tb}^{3+}$-Doped $\mathrm{Lu}_{2} \mathrm{O}_{3}$ Persistent Luminescence Materials. ACS Appl. Mater. Interfaces 2016, 8 , 19593-19604. [CrossRef] [PubMed]

59. Wiktorczyk, T. Optical properties of electron beam deposited lutetium oxide thin films. Opt. Applicata 2001, 31, 83-92.

60. Strek, W.; Zych, E.; Hreniak, D. Size effects on optical properties of $\mathrm{Lu}_{2} \mathrm{O}_{3}: \mathrm{Eu}^{3+}$ nanocrystallites. J. Alloy. Compd. 2002, 344, 332-336. [CrossRef] 